\title{
GREEN BONDS AS A TRANSFER OF SUSTAINABLE DEVELOPMENT IDEA INTO FINANCIAL SECTOR
}

\author{
KRYSTYNA BRZOZOWSKA \\ University of Szczecin, POLAND \\ e-mail: krystyna.brzozowska@wzieu.pl
}

RECEIVED

ACCEPTED

JEL

CLASSIFICATION

KEYWORDS

ABSTRACT
10 May 2018

20 September 2018

F64, G21, G23, 013

sustainable development, financial institutions, green bonds, green bond markets

The aim of a paper is to evaluate a development of green bonds - bonds issued by banks and dedicated to help in resolving sustainable development problems. Research is based on overview of literature regarding to issues of sustainable development, bonds, capital markets approach to sustainable development idea, and published data.

Generally financial institutions and markets are focused on activities against climate changes in the world. Green bonds were created to fund projects with positive environmental benefits. Green bonds allow investors to use the debt capital market to fund climate-related projects. Their structure, risks and returns are identical to those of traditional bonds. The only difference is that the proceeds from the issuance of a green bond are used solely to finance "green" projects, or those that are environmentally friendly. Possible projects covered by green bond funding should be connected to renewable energy, energy efficiency, sustainable waste management, sustainable land use.

The green bond market started in 2007 by European Investment Bank and the World Bank Group. From the beginning to 2012 the increase of value of issued green bonds was rather modest, but in 2014 result was 2 times bigger than in previous year. In 2017 green bond market amounted near $\$ 156$ billion and the same it was a sharp growth of about $78 \%$ in relation to 2016 . Europe accounted for $48 \%$ of the global green bonds market issuances. Poland has also started as issuer of green bonds with 2 very successful transactions run in 2016-2017.

\section{Introduction}

Growing economies have caused an increase of main country ratios like GDP from one side, and still decrease of environment with deepening level of pollution of earth, air, water, forests, etc. from other side. Protection of environment has become one of the most important priorities worldwide and global mobilization to their achievement. Public concern about poverty, hunger, disease, unmet schooling, gender inequality, and 
environmental degradation lead to expanding an idea of sustainable development. Problems of sustainable development have been more and more often underlined at debates, recommendations, strategies of important institutions; corporations, social organizations and financial institutions.

Almost all countries, global and local institutions, social lobbies have undertook a lot of efforts to promote and fulfill sustainable development priorities. Financial sector also - in global, country and local scale - have presented more and more serious attitudes to widespread actions against sustainable development threats, especially in the last 10 years. Global financial institutions have taken an active position in a battle with imbalance of natural, economy and social environment. Idea of sustainable development has been reflected in their strategies and current activities.

The aim of a paper - of contributive nature - is to evaluate a development of green bonds - special bonds issued by banks and dedicated to resolve sustainable development problems. Research is based on thematic literature regarding to issues of sustainable development and data published mainly by World Bank and Climate Bond Initiative.

\section{Litepature review}

Framing of sustainable development was started in early 80 . as a trial to overcome a gap between environmental problems, with increasing numbers of negative examples of environmental results of human activity and social-political aspects of human development (Mebratu, 1998; Lozano, 2008).

Defining sustainable development in all aspects is a challenge because of its interdisciplinary nature (environment, economy, social and political issues) (Robinson, 2003).

Sustainable development, meaning economic growth that is environmentally sound, is a practical necessity. Environmental goals cannot be achieved without development (Sachs, Reid, 2006). Another definition underlined that sustainable development - process or evolution - is a development that meets the needs of the present without compromising the ability of future generations to meet their own needs (Brundland et al., 1987). This aspect was also underlined by Glavic and Lukman, who emphasized that sustainable development is the evolution of human society from the responsible economic point of view in accordance with environmental and natural processes (Glavic, Lukman, 2007).

Sustainable development idea is reflected in financial products and services provided by main financial institutions. Generally financial institutions and markets are focused on activities against climate changes in the world, and more often have implemented special designed products and product lines to finance projects to diminish climate changes or adopt environment to effects of climate changes.

\section{Resullts}

Green bonds, as the name implies, are conventional bonds that feature an environmentally conscious use of their proceeds. Green bonds were created to fund projects with positive environmental and/or climate benefits. They allow investors to use the debt capital market to fund climate-related projects. Such activity has been undertaken by leading multilateral institutions, like as European Investment Bank, European Bank of Reconstruction and Development, International Bank of Reconstruction and Development as a part of World Bank Group. Other important issuers: Ginnie Mae and Fannie Mae - bonds secured by mortgage labeled „green”, EIB, Meryll Lynch, 
Barclays, HSBC, Bank of China. Green bonds also help investors diversify their portfolios while contributing to the well-being of the environment.

Structure, risks and returns of green bonds are identical to those of traditional papers (Table 1). The only difference is that the proceeds from the issuance of a green bond are used solely to finance "green" projects, or those that are environmentally friendly.

Table 1. Main features of green bonds

- Designated instrument (green labeled)

- Debt financial instrument with fix interest rates

- Capital reimbursed to investors after expiration date

- Interests reimbursed according to coupon formula in whole period of validity

- A purchase of green bonds is treated in terms of tax preferences (in many countries)

Source: OECD (2015).

Green bonds usually must undergo third-part verification to establish that the proceeds are funding projects that generate environmental benefits (Green Bonds, 2016) or investors to ensure that their investment is being used appropriately for an environmental cause, green bonds need to offer transparency. Possible projects covered by green bond funding should be connected to renewable energy, energy efficiency, sustainable waste management, sustainable land use (forestry and agriculture), biodiversity, clean transportation and clean water (compare to Table 2).

Table 2. Categories and Sub-categories of selection to Green bond Use of Proceeds

\begin{tabular}{|c|c|}
\hline Green Bond Category & Sub-category \\
\hline Alternative energy & $\begin{array}{l}\text { Wind, solar, geothermal, biomass, waste energy, wave tidal, small hydro (<25 MW), biogas, bio-fuels } \\
\text { (first and second generation). }\end{array}$ \\
\hline Energy efficiency & $\begin{array}{l}\text { Demand-side management, battery, fuel cells/hydrogen systems, smart grid, other energy storage, } \\
\text { superconductors, natural gas combined heat\& power, LED lighting, compact fluorescent lighting, insulation, hybrid/ } \\
\text { electric vehicles, clean transportation infrastructure, industrial automation, IT optimization service \& infrastructure. }\end{array}$ \\
\hline Pollution prevention \& Control & $\begin{array}{l}\text { Environmental remediation, waste treatment (excluding landfill and incineration), reuse \& recycling of waste, low } \\
\text { toxicity/VOC, conventional pollution control. }\end{array}$ \\
\hline Sustainable water & $\begin{array}{l}\text { Water infrastructure and distribution (with impact on waste quality and access), rainwater harvesting, smart } \\
\text { metering devices, drought-resistant seeds, desalinization, waste water treatment, water recycling equipment } \\
\text { and services, watershed conservation efforts,. }\end{array}$ \\
\hline Green buildings & $\begin{array}{l}\text { Green certified residential and commercial properties based on local environmental performance standards, green } \\
\text { certified residential and commercial properties based on local environmental design standards, uncertified green } \\
\text { property investments (top } 15 \% \text { energy efficiency within local market. }\end{array}$ \\
\hline
\end{tabular}

Source: Barclays... (2014) .

Green bonds can be issued as government, municipal, corporate or financial institutions securities in form of standard (corporate, municipal, multilateral, agency) with re-course to issuer with the same rating note to bonds and the issuer, with non-re-course to issuer and secured by project revenues, project bonds to one or many projects with recourse or no recourse to issuer, and securitized bonds (www.climatechange.net, 2016). It should be underlined a significant role that governments play in supporting the green bond market by adequately utilizing 
public capital in funding environmental projects. Government standardization and policies can also increase the issuance of labeled bonds (Labeled..., 2017).

A green label provides additional transparency to investors by disclosing the types of projects a bond will finance. A much broader universe of "unlabeled" green bonds exists, but investors are increasingly seeking the transparency that labeled green bonds provide so that they can better assess the impact their investment is making. Because self-labeling of green bonds didn't provide sufficient assurance to investors, the International Capital Market Association (ICMA) created four Green Bond Principles to provide more transparency (Table 3).

Table 3. Green Bond Principles

\begin{tabular}{ll}
\hline \multicolumn{1}{c}{ Name of rule } & \multicolumn{1}{c}{ Explication } \\
\hline Use of proceeds & $\begin{array}{l}\text { the issuer should declare the eligible green project categories if intend to support, and clear definition of the } \\
\text { environmental benefits connected to the project finance by proceeds. } \\
\text { it should be underlined that decision making process follows the eligibility of individual investments using the green } \\
\text { bonds proceeds. } \\
\text { the proceeds should be moved to a sub-portfolio or otherwise attested to by a formal internal process. } \\
\text { the issuer should report at least annually on the investments made from the proceeds, detailing all the environmental } \\
\text { benefits. }\end{array}$ \\
\hline
\end{tabular}

Source: by own based on Green Bond Highlights 2017 (2018).

Green bonds are listed in some stock exchanges, like as London, Oslo, Stockholm, Luxembourg, Johannesburg, and Mexico. Since 2014 number of ratings agencies and financial institutions have created indices to exclusively cover green bonds. The first one was Solactive Green Bond Index, and few months later S\&P Green Bond Index and Green Project Bond Index, Bank of America Merill Lynch Green Bond Index, and the most known Barclays $\mathrm{MSCl}$ Green Bond Index. The launch of numerous green bond indices is a sign of the market's growing maturity. Moreover, these indices are playing an important role for driving demand for green bonds among institutional investors (Summary..., 2017).

\section{Results supply}

The green bond market started in 2007 by the European Investment Bank and the World Bank. The World Bank Group has been a pioneer in the green bond market issuing a first green bond in 2008. Since then World Bank's global issuances to institutional and retail investors have reached up to $\$ 10$ billion in 18 currencies through near 130 transactions, World Bank supports this way projects that will reduce $\mathrm{CO}_{2}$ emissions, increase energy savings, power generation from renewable sources, improve water management and restore forests.

The market has gained popularity among investors as a way to climate-proof their portfolios and still enjoy a diversified benefits. The market has grown considerably in the last ten years. Dynamic increase of green bonds issuance activity can be treated as coherency of worsening environment conditions to sustainable development, necessity of leveling effects of climate and environment changes, and needs in new projects fully eligible to environmental criteria.

From the beginning to 2012 the increase of value of issued green bonds was rather modest, but in 2014 result was 2 times bigger than in previous year. The same proportions appeared in 2016 to 2015 (Figure 1). 


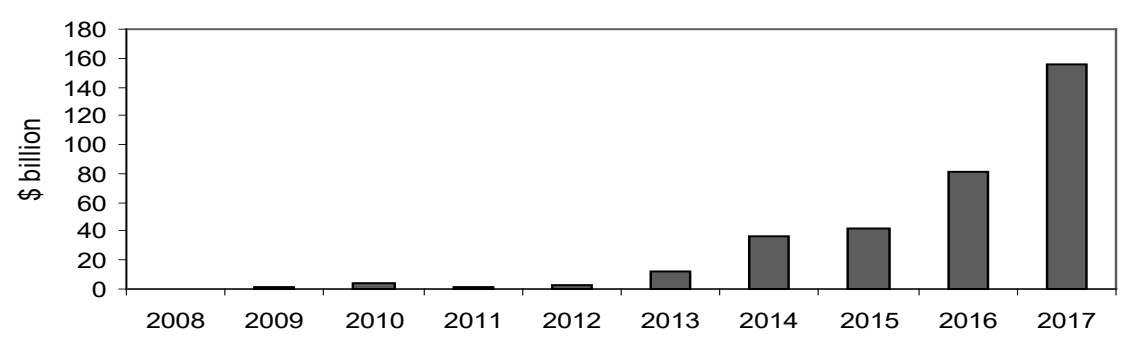

Figure 1. World issuance of green bonds (\$billion)

Source: by own based on Green Bond Highlights 20172018.

In 2017 green bond market amounted $\$ 155.5$ billion and the same it was a sharp growth of about $78 \%$ in relation to 2016 with over 1,500 issuances prepared by 239 different issuers in 37 countries on all 6 continents. The largest single green bond issuance was for $\$ 10,7$ billion.

The last 2 years changes were marked also in share of labeled green bonds - in 2016 labeled green bonds amounted to $17 \%$ of value of total issued 'climate aligned' bonds, while in 2017 such share increased to $25 \%$.

Proceeds from green bonds in 2017 have been spent mainly for projects of 4 sectors: renewable energy, energy efficiency, transport, and water management (Figure 2).

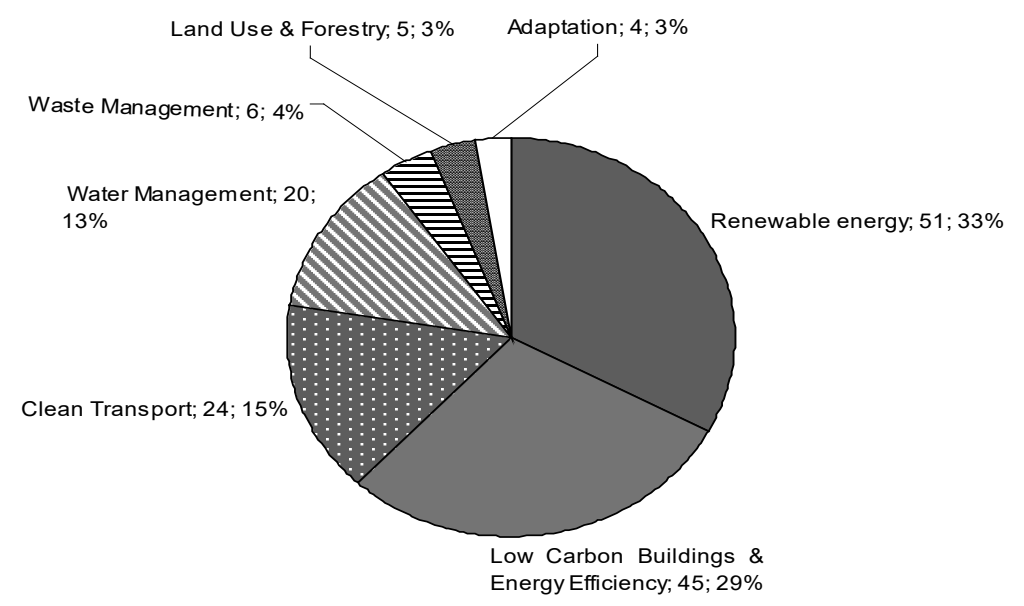

Figure 2. Green Bond 2017 Issuance by Sector

Source: Climate Bond Initiative. Data as Sep. 29.2017.

The United States was a ultimate leader in green bonds market in a whole, second place from the last 4 years is occupied by China and the next a few of European countries. These relation is presented on Figure 3. 


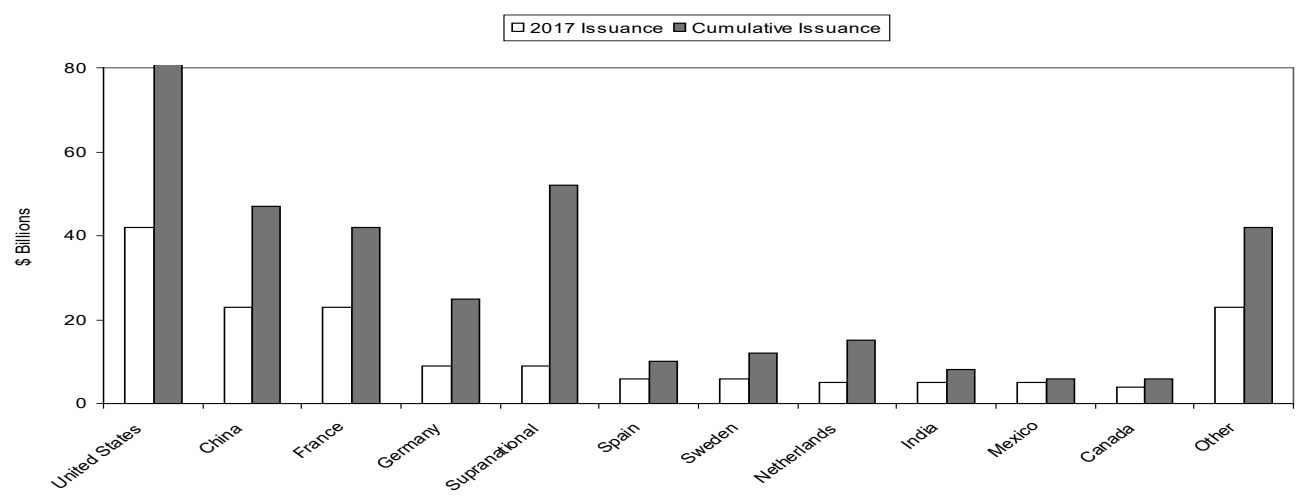

Figure 3. Cumulative and 2017 issuance of green bonds

Source: Green Bond Highlights 2017 (2018).

Europe (France, Germany, Netherlands, Sweden, Spain) has represented over $48 \%$ of total issuances in 2017, the next North America (16\%) with the United States and Asia (23\%) with China (compare Figure 4).

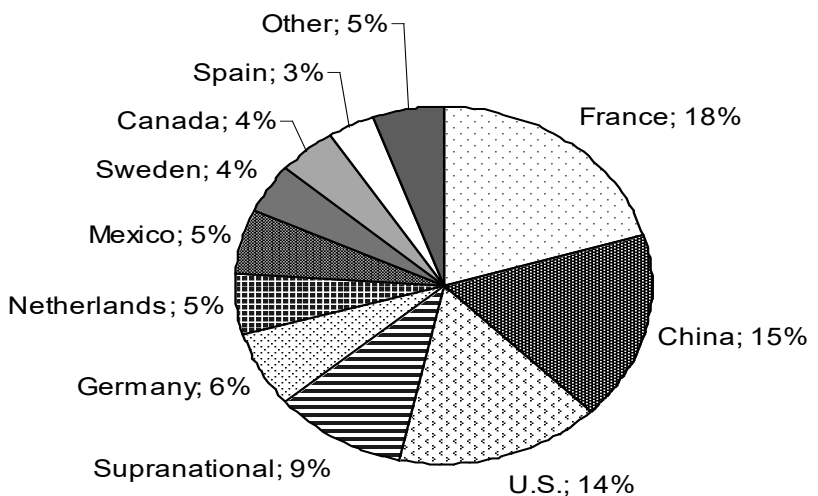

Figure 4. Green Bond 2017 Issuance by Country

Source: Climate Bond Initiative. Data as Sep. 29.2017.

In 2017 Europe accounted for $48 \%$ of the global green bonds market issuance. European issuers have dominated global issuance this year with nearly $\$ 38$ billion of green bonds issued versus $\$ 22$ billion in 2016 . France accounts for $40 \%$ of this starting with a $\$ 7.5$ billion green bond and a $\$ 527.4$ million sovereign green bond issued by French public sector financial institution. Sweden issued its third green bond worth $\$ 500.0$ million. Denmark has debuted into the green bond market with $\$ 559.1$ million issued by its local government funding agency. In Norway municipality-owned power company issued its inaugural five year green bond worth $\$ 58.2$ million (Europe..., 2017).

Poland, like as France, in the end of 2016 started into green bond market with issue of $€ 720$ million 5-year sovereign green bonds. This transaction was finished immediately with great success of issuer. The main objective 
of the issue was to finance or refinance project with positive impact on the environment (Poland's, 2017). At the beginning of 2018 Poland issued next sovereign 8.5-year EUR denominated green bonds for value EUR 1 billion. Demand for Polish green bonds exceeded EUR 3,6 billion. Proceeds from the issuance will be spent also on environmental projects (EUR, 2018).

\section{Conclusions}

The growth of bond markets provides a wide opportunities to finance green economy projects. Green bonds can stimulate financial, economy and regulatory reforms to boost green growth and can help countries make changes into low carbon economies. Preparing highly specialized financial instrument, as green bond is, has to insert a great and deep efforts to recognize problems of unsustainable development problems. Its worthy to quote that "processes connected to green bonds issuances will accelerate sharply and will create a market by 2020 more 10 times bonds issued in 2016" (Figueres et al., 2017), it means $\$ 1$ trillion for green finance.

\section{References}

Barclays MSCI Green Bond Indices Bringing clarity to the green bond market through benchmark indices (2014). Retrieved from: www. msci.com/eqb/methodology/meth_docs (18.01.2017), 7.

Bloomberg global fixed-income league tables 2016 (2017). Retrieved from: https://data.bloomberglp.com/professional/sites/4/ Bloomberg-League-Global-Fixed-Income.pdf (22.01.2017).

Brundtland, G, Khalid, M, Agnelli, S, Al-Athel, S, Chidzero, B, Fadika, L. (1987). Our Common Future - The World Commission on Environment and Development. Oxford, UK: Oxford University Press.

EUR Green bonds priced (2018). Retrieved from: http://www.mf.gov.pl/en/news/-/asset_publisher/X7ac/content/eur-green-bondspriced (24.02.2018).

Europe dominates global green bonds issuance in 2017 (2017). Retrieved from: https://marketrealist.com/2017/11/growth-expectedgreen-bonds (9.02.2018).

Figueres, Ch., Schellhuber, H.J., Whiteman, G., Rockstrom, J, Hobley, A., Rahmstorf, S. (2017). Three years to safeguard our climate. Nature, 546, 593-595.

Glavic, P., Lukman, R. (2007). Review of sustainability terms and their definitions. Journal of Cleaner Production, 15, $1876-1884$.

Green Bond Highlights 2017 (2018). Climate bonds. Retrieved from: www.climatebond.net (23.02.2018).

Green Bonds (2016). Retrieved from: www.undp.org/content/sdfinance/en/home/solutions/green-bonds.html 26.2.2016. (18.01.2017).

HSBC, Bonds and Climate Change. The State of the market in 2016 (2016). Retrieved from: www.climatechange.net (16.12.2016).

ICMA, Green Bond Principles (2017). https://www.icmagroup.org/assets/documents/Regulatory/Green-Bonds/GreenBondsBrochureJUNE2017.pdf (25.02.2018).

Labeled green bonds' significance investors (2017). Market realist, https://marketrealist.com/2017/11/labeled-green-bonds-significanceinvestors (9.02.2018).

Lozano, R. (2008). Envisioning sustainability three - dimensionally. Journal of Cleaner Production, 16, 1838- 1845.

Mebratu, D. (1998). Sustainability and sustainable development: historical and conceptual review. Environmental Impact Assessment Review, 18, 493-520.

OECD, Green bonds. Mobilising the debt capital markets for a low-carbon transition. Policy perspectives (2015). Retrieved from: https:// www.oecd.org/environment/cc/Green\%20bonds\%20PP\%20\%5Bf3\%5D\%20\%5BIr\%5D.pdf (24.02.2018).

Poland's green bond - Q\&A with the Deputy Minister of Finance. Retrieved from: www.environmental-finance.com/content/analysis. polands-green-bond-q-and-a-with-the-deputy--minister-of-finance (18.01.2017).

Robinson, J. (2004). Squaring the circle? Some thoughts on the idea of sustainable development. Ecological Economics, $48,370$.

Sachs, J.O.(2012). From Millennium Development Goals to Sustainable Development Goals. Lancet, 379, 2206.

Sachs, J.O., Reid, W.V. (2006). Investment towards Sustainable Development. Science, 312, 1002. 
Summary of Green Fixed Income Indices Providers (2017). The GBP Databases and Indices Working Group. Retrieved from: https:// www.icmagroup.org/assets/documents/Regulatory/GreenBonds/Green-Bond-Indices-Summary-Document-190617.pdf. (23.02.2018).

The World Bank Green Bond. Impact Report June 2016 (2016). Retrieved from: https:// treasury.worldbank.org/cmd/htm/ WorldBankGreenBondNewsletters.html (16.01.2017).

www.climatebonds.net (16.01.2017).

Cite this article aS: Brzozowska, K. (2018). Green bonds as a transfer of sustainable development idea into financial sector. European Journal of Service Management, 3 (27/1), 15-22. DOI: 10.18276/ejsm.2018.27/1-02. 